\title{
ESENSI HUTANG DALAM KEUANGAN RUMAH TANGGA YANG ISLAMI
}

\author{
Moh Agus Nugroho*
}

\begin{abstract}
:
Debt is permissible in Islam, but debt can bring a person to heaven because of his intention to please help his fellow human beings (hablun minannaas), debt can also bring a person into the fire of hell when not managed properly. So the debt becomes the last alternative is not the first done if the household finances are not stable. Financial management with the corridor of the fulfillment of the benefit can reduce the risk of household financial instability, by making family financial planning aimed at achieving falah (prosperous world and the hereafter), avoiding maisir ways, gharar, riba and unjust both in collecting income and in spend it, give priority to sadaqah even though rizki is narrow, and away from nature wasteful. Keywords: debt, finance, Islamic household
\end{abstract}

\section{A. Pendahuluan}

Sering dijumpai keluarga yang mengalami konflik karena permasalahan keuangan. Konflik dalam keuangan memang tidak baik untuk keutuhan keluarga, karena hal ini dapat mengakibatkan perpecahan, retaknya hubungan pasangan suami istri bahkan bisa berakibad perceraian. Hal ini dikuatkan hasil penelitian di Amerika yang menunjukan bahwa terdapat sekitar 56\% dari permasalahan perceraian disebabkan oleh adanya konflik keuangan dalam rumah tangga. ${ }^{241}$

241 Lewis Mandell and Linda Schemid Klein, "The Impact of Financial Literacy Education on Subsequent Financial Behavior", Journal of Financial Counseling and Planning, Volume 20 Issue 1 tahun 2009, hlm. 85. 
Jika keuangan keluarga tidak dikelola dengan baik maka keluarga tersebut secara financial akan mengalami berbagai keterbatasan, dan tentunya akan mengakibakan tekanan emosional, mental, sosial, hubungan spritual, dan malas meningkatkan potensi dan keterampilan. Berbagai alasan tersebut, untuk menutupi malasah keuangan dalam rumah tangga dengan cara berhutang, untuk mendapatkan modal sehingga berharap keuangan rumah tangga bisa membaik. $^{242}$

Dalam konsep Islam, utang piutang merupakan akad (transaksi ekonomi) yang mengandung nilai ta'awun (tolong menolong). Dengan demikian utang piutang dapat dikatakan sebagai ibadah sosial yang dalam pandangan Islam juga mendapatkan porsi tersendiri. Utang piutang juga memiliki nilai luar biasa terutama guna membantu antar sesama bagi yang tidak mampu secara ekonomi atau sedang membutuhkan.

Hukum hutang piutang dapat berubah menjadi haram apabila diketahui bahwa dengan berhutang seseorang bermaksud menganiaya orang yang memberikan hutang atau orang yang berhutang tersebut akan memanfaatkan orang yang diberikan hutang itu untuk berbuat maksiat. Dalam kondisi demikian, maka hutang piutang berorientasi pada perbuatan tolong menolong dalam kemaksiatan dan haram hukumnya. Maka dari itu, berdasarkan pada kondisi yang saat bervariasi, hukum hutang piutangpun amat bervariasi pula seperti wajib, haram, makruh dan mubah. ${ }^{243}$

Dewasa ini hutang bagaikan sebuah pisau bermata dua. Disatu

242 Syaparuddin, "Pengelolaan Keuangan Keluarga Secara Profesional Dalam Mewujudkan Keluarga Sakinah", AlRisalah-Jurnal Hukum Keluarga Islam, Volume 1 No. 1 Juli 2014. hlm.76-91

243 Ady Cahyadi, "Mengelolah Hutang Dalam Perspektif Islam", Esensi-jurnal Bisnis dan Manajemen. Vol. 4, No.1, 2014. hlm. 68 
sisi hutang dapat menolong seseorang atau keluarga lepas dari kesulitan namun di sisi yang lain hutang juga dapat menjerat dan menyusahkan seseorang ataupun membangkrutkan sebuah keluarga karena lilitan hutang. Pengelolaan keuangan yang baik sangat dibutuhkan agar sebuah keluarga dapat terbebas dari hutang bahkan mencapai keluarga yang sejaterah dalam ekonominya.

Jika demikian adanya, maka hal ini menjadi sangat urgen untuk dibahas dalam tulisan ini karena dapat memberikan solusi alternatif, dan juga dapat dijadikan sebagai rujukan dalam mewujudkan sebuah keluarga sakinah, sehingga keretakan dalam rumah tangga yang dapat menyebabkan perceraian akibat persoalan keuangan dapat dihindari. Adapun fokus pembahasan yaitu bagaimana pengelolaan keuangan dalam rumah tangga dalam ekonomi Islam dan esensi berhutang dalam keuangan keluarga Islami.

\section{B. Metode Penelitian}

Penelitian ini menggunakan pendekatan kualitatif dengan pendekatan literature review esensi hutang dan pengelolaan keuangan rumah tangga secara Islami, sedangkan data sekunder yang digunakan berupa data-data hasil petikan dari portal berita internet/website. Tujuan literature review adalah untuk mendapatkan landasan teori yang bisa mendukung pemecahan masalah yang sedang diteliti, tujuan lain dari literature review ini adalah untuk mendapatkan gambaran yang berkenaan dengan apa yang sudah dikerjakan orang lain sebelumnya. Literature review berisi uraian tentang teori, temuan dan bahan penelitian lain yang diperoleh dari bahan acuan untuk dijadikan landasan kegiatan penelitian. ${ }^{244}$ 


\section{Pembahasan}

1. Keluarga dan Permasalahan Keuangan

Keluarga sebagai kelompok sosial terdiri dari sejumlah individu, memiliki hubungan antar individu, terdapat ikatan, kewajiban, tanggung jawab di antara individu tersebut. Keluarga yang berasal dari bahasa Sansekerta, yaitu: kulawarga yakni: ras dan warga yang berarti anggota, adalah lingkungan yang terdapat beberapa orang yang masih memiliki hubungan darah. ${ }^{245}$ Jadi, keluarga adalah unit terkecil dari masyarakat yang terdiri atas kepala keluarga dan beberapa orang yang terkumpul dan tinggal di suatu tempat di bawah suatu atap dalam keadaan saling ketergantungan.

Mengutip pendapat Salvicion dan Celis, Baron mengatakan bahwa di dalam keluarga terdapat dua atau lebih dari dua pribadi yang tergabung karena hubungan darah, hubungan perkawinan atau pengangkatan, di hidupnya dalam satu rumah tangga, berinteraksi satu sama lain dan di dalam perannya masing-masing dan menciptakan serta mempertahankan suatu kebudayaan. ${ }^{246}$ Dengan demikian, keluarga berperan menggambarkan seperangkat perilaku antar pribadi, sifat, kegiatan yang berhubungan dengan pribadi dalam posisi dan situasi tertentu.Peranan pribadi dalam keluarga didasari oleh harapan dan pola perilaku dari keluarga, kelompok dan masyarakat.

Berbagai peranan yang terdapat dalam keluarga, yaitu: Ayah sebagai suami dari isteri dan ayah dari anak-anaknya, berperan sebagai pencari nafkah, pendidik, pelindung dan pemberi rasa aman, sebagai kepala keluarga, sebagai anggota dari kelompok sosialnya serta

245 Syaparuddin, "Pengelolaan Keuangan Keluarga Secara Profesional Dalam Mewujudkan Keluarga Sakinah", AlRisalah-Jurnal Hukum Keluarga Islam, Volume 1 No. 1 Juli 2014. hlm.76-91

246 R. A. Baron dan Donn Byrne, Psikologi Sosial, Terj. (Jakarta: Erlangga, 2003), hlm. 67. 
sebagai anggota dari kelompok sosialnya serta sebagai anggota masyarakat dari lingkungannya. Sebagai istri dan ibu dari anakanaknya, ibu mempunyai peranan untuk mengurus rumah tangga, sebagai pengasuh dan pendidik anak-anaknya, pelindung dan sebagai salah satu kelompok dari peranan sosialnya serta sebagai anggota masyarakat dari lingkungannya, disamping itu juga ibu dapat berperan sebagai pencari nafkah tambahan dalam keluarganya. Anak-anak melaksanakan peranan psikosial sesuai dengan tingkat perkembangannya baik fisik, mental, sosial, dan spiritual. ${ }^{247}$

Selain hal tersebut di atas, agar harmonis sebuah keluarga juga harus menjalankan berbagai macam fungsi, yaitu:

a. Fungsi Pendidikan dilihat dari bagaimana keluarga mendidik dan menyekolahkan anak untuk mempersiapkan kedewasaan dan masa depan anak.

b. Fungsi Sosialisasi anak dilihat dari bagaimana keluarga mempersiapkan anak menjadi anggota masyarakat yang baik.

c. Fungsi Perlindungan dilihat dari bagaimana keluarga melindungi anak sehingga anggota keluarga merasa terlindung dan merasa aman.

d. Fungsi Perasaan dilihat dari bagaimana keluarga secara instuitif merasakan perasaan dan suasana anak dan anggota yang lain dalam berkomunikasi dan berinteraksi antar sesama anggota keluarga. Sehingga saling pengertian satu sama lain dalam menumbuhkan keharmonisan dalam keluarga.

e. Fungsi Agama dilihat dari bagaimana keluarga memperkenalkan dan mengajak anak dan anggota keluarga lain melalui kepala

${ }^{247}$ Anita L. Vangelis, Handbook of Family Comunication (USA:Lawrence Elbraum Press, 2004), hlm. 349. 
keluarga menanamkan keyakinan yang mengatur kehidupan kini dan kehidupan lain setelah dunia.

f. Fungsi Ekonomi dilihat dari bagaimana kepala keluarga mencari penghasilan, mengatur penghasilan sedemikian rupa sehingga dapat memenuhi kebutuhan-kebutuhan keluarga.

g. Fungsi Rekreatif dilihat dari bagaimana menciptakan suasana yang menyenangkan dalam keluarga, seperti acara nonton TV bersama, bercerita tentang pengalaman masing-masing, dan lainnya, dan

h. Fungsi Biologis dilihat dari bagaimana keluarga meneruskan keturunan sebagai generasi selanjutnya. ${ }^{248}$

Terkait dengan fungsi ekonomi di atas, saat ini banyak aturan finansial telah berubah, penyebabnya adalah ekonomi yang tidak menentu, cara berbelanja dan menabung, serta gaya hidup yang berubah. Akibatnya, semakin banyak orang merasa semakin sulit mengatur keuangan pribadi dan keluarganya. Akhirnya, banyak orang yang terlilit utang, gaya hidup modern membuat banyak pengeluaran yang membuat problem keuangan bertambah. Karena itu, harus diyakini bahwa tidak ada masalah yang tidak bisa dipecahkan jika berpikir dengan jernih untuk mencari solusi yang dilandasi dengan cara yang baik sehingga tercapai kesepakatan bersama. Hal ini dilakukan agar cita-cita dalam mewujudkan keluarga sakinah, menjadi suatu realita pada keluarga kita. Dengan demikian, salah satu faktor penting yang membentuk nuansa keharmonisan dalam rumah tangga adalah pengelolaan keuangan keluarga yang benar dan tepat. ${ }^{249}$

Namun perlu digaris bawahi bahwa dalam mengelola keuangan

248 Richard R Clayton, The Family, Mariage and Social Change (USA:Lawrence Elbraum Press, 2003), hlm. 58-60.

249 Syaparuddin, "Pengelolaan Keuangan Keluarga Secara Profesional Dalam Mewujudkan Keluarga Sakinah", AlRisalah-Jurnal Hukum Keluarga Islam, Volume 1 No. 1 Juli 2014. hlm.76-91. 
keluarga tidak ada ketentuan yang mengharuskan suami menyerahkan semua penghasilannya kepada istri. Dalam hal ini, yang menjadi kewajiban suami adalah memberi nafkah, pakaian, dan tempat tinggal layak untuk istri dan anak-anaknya. Sedangkan istri bertugas sebagai bendahara/pengelola keuangan rumah tangga. Suami bertugas melakukan cek, evaluasi, serta persetujuan terhadap perencanaan keuangan yang diatur istri. Dalam sebuah hadits, Rasululah saw. menegaskan bahwa istri adalah pemimpin di dalam rumah tangga suaminya dan bertanggung jawab atas tugas kepemimpinanya tersebut.

Sebagai seorang bendahara dan pemimpin rumah tangga suami, istri harus diberikan keleluasaan untuk mengatur pembelanjaan sesuai dengan rencana yang disepakati. Oleh karena itu, bila memiliki rencana untuk membantu orang tua harus dimusyawarahkan di antara keluarga dengan sebaik-baiknya. Hak-hak istri dan anak-anak tidak boleh terabaikan, baik untuk masa kini dan masa depan. Dengan begitu tidak ada kecurigaan dari istri. Jika suami dan istri terbuka dalam mengungkapkan keinginan, saling memahami, serta selalu bermusyawarah mencapai kata sepakat termasuk dalam urusan keuangan, maka tidak akan terjadi konflik pada keluarga. ${ }^{250}$ Jadi, komunikasi yang baik antara suami istri adalah modal utama untuk sukses dalam mengelola keuangan keluarga. Untuk ini, tindakan menyembunyikan masalah keuangan keluarga dari pasangan harus dihindari, dan jangan mengacuhkan atau menunda penyelesaian masalah-masalah keuangan tersebut karena makin lama ditunda akan makin membahayakan kondisi keuangan keluarga.

2. Perencanaan Keuangan Keluarga Secara Profesional

250 S Minuchin, Families and Family Therapy (Cambridge, MA: Harvard University Press, 1999), hlm. 349. 
Dalam Islam membuat perencanaan keuangan keluarga harus bertujuan untuk mencapai falah (sejahtera dunia dan akhirat), menghindari cara-cara yang maisir, gharar, riba dan zalim baik dalam mengumpulkan pendapatan maupun dalam membelanjakannya, mengutamakan sadaqah meskipun rizki sedang sempit, dan menjauhi sifat boros.

Secara teknis membuat perencanaan keuangan keluarga tidaklah susah atau rumit diterapkan. Namun sayangnya, ilmu perencanaan keuangan keluarga tidak atau jarang diajarkan di lembaga-lembaga formal. Manajemen keuangan yang dipelajari di lembaga-lembaga formal adalah manajemen keuangan untuk perusahaan (corporate finance). Mengutip pendapat Antony Japari, hal awal yang harus dilakukan dalam membuat perencanaan keuangan keluarga secara profesional agar tujuan tersebut di atas dapat tercapai, yaitu: (1) menentukan tujuan keuang an keluarga, baik jangka pendek, menengah, dan panjang, (2) mengetahui kemampuan keuangan saat ini dan potensi keuangan di masa depan, (3) membuat laporan arus kas, laporan neraca, dan anggaran keuangan keluarga, (4) dalam melakukan investasi, profil risiko pribadi perlu diketahui, apakah konservatif, moderat. atau agresif, dan (5) mengetahui cara atau model perencanaan keuangan yang efektif dan mudah dipahami. ${ }^{251}$

\section{Aturan Penggunaan Keuangan dalam Keluarga}

Seorang kepala rumah tangga yang berpenghasilan ratusan juta rupiah bisa mengalami shock ketika menemukan uangnya tinggal Rp. 500.000 sebelum akhir bulan. Karena itu aturan penggunaan keuangan dalam keluarga harus dapat dipahami dan diterapkan dengan baik jika

251 Antony Japari, "Konsep Perencanaan Keuangan Keluarga", Dokumen Internal, Financial Planner Assosiasi Indonesia, 23 Agustus 2012. 
tidak ingin shock sebelum akhir bulan. Jika mengacu pada kerangka pengelolaan keuangan dalam Islam yaitu untuk mencapai falah dan tahapan untuk mencapai falah maka pemanfaatan pendapatan harus mencakup tujuan kebahagiaan hidup di dunia dan kesuksesan hidup di akhirat.

Pernyataan di atas mensiratkan bahwa masalah keuangan keluarga bukan terletak pada penghasilan yang kurang, tapi kebiasaan yang salah dalam mengelola uang. Jika demikian adanya, maka secara sederhana menurut Ligwina hal-hal yang harus diperhatikan dalam menggunakan keuangan dalam keluarga, yaitu: ${ }^{252}$

Pertama, memahami portfolio keuangan keluarga. Setiap kepala rumah tangga harus tahu isi tabungannya, jumlah tagihan listrik, telepon, servis mobil, belanja, biaya periksa dokter dan lainnya. Demikian juga harus tahu berapa hutang kartu kredit, pinjaman bank atau cicilan rumah dan mobil.

Kedua, menyusun rencana keuangan atau anggaran. Rencana keuangan yang realistis membantu setiap keluarga bersikap obyektif soal pengeluaran yang berlebihan. Tidak perlu terlalu ideal, sehingga lupa kebutuhan diri sendiri. Namun, tak ada salahnya memasukkan kebutuhan pergi ke salon, spa atau clubbing, yang penting harus dianggarkan jumlah yang realistis dan patuh dengan anggaran tersebut.

Ketiga, memikirkan lebih seksama pengertian antara "butuh" dan "ingin". Orang sering membelanjakan uang untuk hal yang tak terlalu penting atau hanya didorong keinginan, bukan kebutuhan. Karena itu, kita harus membuat daftar berupa tabel yang terdiri dari kolom untuk item belanja, kebutuhan dan keinginan. Setelah mengisi

252 Liqwina, "Cara Sederhana Mengelola Keuangan Keluarga", Dokumen Internal, Financial Planner Assosiasi Indonesia, 23 Agustus 2012. 
kolom item belanja, kolom "kebutuhan" dan "keinginan" harus diisi dengan tanda cek (V). Dari sini dapat dipertimbangkan dengan lebih matang tentang benda atau hal yang perlu dibeli/penuhi atau tidak.

Keempat, menghindari hutang. Godaan untuk hidup konsumtif semakin besar. Namun bukan berarti dengan mudah kita bisa membeli berbagai benda secara kredit. Karena itu, kita harus bisa menumbuhkan kebiasaan keuangan yang sehat dimulai dari yang sederhana, seperti tak memiliki hutang konsumtif.

Kelima, meminimalkan belanja konsumtif. Bertemu teman lama untuk bertukar pikiran di kafe terkadang memang perlu, tapi tak berarti kita harus melakukannya di setiap Jumat sore. Kita bisa gunakan pengeluaran ini untuk menabung atau memenuhi kebutuhan lain.

Keenam, menetapkan tujuan atau cita-cita finansial. Kita harus bisa menyusun target keuangan yang ingin dicapai secara berkala, bersama pasangan. Dengan demikian, tujuan spesifik, realistis, terukur dan dalam kurun waktu tertentu harus ditetapkan. Tujuan ini membantu kita lebih fokus merancang keuangan. Misalnya, bercitacita punya dana pendidikan prasekolah berstandar internasional dan sebagainya.

Ketujuh, menabung. Kita harus bisa mengubah kebiasaan dan pola pikir segera setelah menerima gaji, menyisihkan sebagian untuk tabungan dalam jumlah yang telah direncanakan sesuai tujuan atau cita-cita finansial keluarga. Sebaiknya, setiap keluarga memiliki rekening terpisah untuk tabungan dan kebutuhan sehari-hari.

Kedelapan, berinvestasi. Tentu kita tidak akan puas dengan hanya menunggu tabungan menjadi banyak, karena setiap keluarga memiliki cita-cita yang sangat banyak. Inilah saat yang tepat untuk 
memikirkan investasi. Kini bentuknya macam-macam. Tak perlu khawatir akan risiko investasi, kita hanya perlu belajar pada ahlinya. Karena itu, kondisi keuangan keluarga harus dikonsultasikan dengan ahli keuangan yang handal.

Dalam konteks keislaman, pengelolaan harta/keuangan yang dilakukan harus dalam koridor pemenuhan kemaslahatan. Sikap ini melahirkan suatu stereotip bahwa dalam Islam membuat perencanaan keuangan keluarga harus bertujuan untuk mencapai falah (sejahtera dunia dan akhirat), menghindari cara-cara yang maisir, gharar, riba dan zalim baik dalam mengumpulkan pendapatan maupun dalam membelanjakannya, serta menghindari hutang mengutamakan sadaqah meskipun rizki sedang sempit, dan menjauhi sifat boros. ${ }^{253}$

4. Esensi Hutang Dalam Rumah Tangga

a. Islam Membolehkan Hutang

Ajaran agama islam membolehkan hutang karena hutang adalah bagian dari tolong menolong sesama manusia (hablun minan naas) sebagaimana dalam beberapa surat dan ayat dalam alquran berikut ini:

"Dan tolong menolonglah kamu dalam kebaikan dan takwa, dan janganlah kamu tolong menolong dalam melakukan kejahatan dan kerusakan.” Al Maidah (5):2

"Jika kamu meminjamkan kepada Allah pinjaman yang baik niscaya Allah melipatgandakan balasannya kepadamu dan mengampuni kamu. Dan Allah maha Pembalas jasa lagi maha Penyantun.” At Taghabun (64):17

Dari banyaknya ayat yang menyinggung tentang pinjaman

${ }^{253}$ Syaparuddin, "Pengelolaan Keuangan Keluarga Secara Profesional Dalam Mewujudkan Keluarga Sakinah", AlRisalah-Jurnal Hukum Keluarga Islam, Volume 1 No. 1 Juli 2014. hlm.76-91 
(hutang) diatas hal itu menunjukkan bahwa hutang (baik yang sifatnya hablun minannaas maupun hablun minallah) mempunyai kedudukan yang penting sehingga perlu diatur dengan baik tata cara dan perlakuannya dalam islam.

\section{b. Prinsip Berhutang}

Utang merupakan suatu yang biasa terjadi dalam kehidupan begitu pula dalam ajaran Islam. Hal ini merupakan sunatullah yang sudah digariskan oleh Allah. Bahkan pada awal ayat surat Al-Baqarah ayat 282, disebutkan bahwa jika seorang yang beriman ingin berutang kepada pihak lain dalam jangka waktu tertentu, maka hendaklah ia mencatatnya. Hal ini menunjukan bahwa utang adalaha hal yang diperbolehkan selama memenuhi sejumlah prinsip dan etika pokok. Adapun prinsip-prinsip utang yang harus diperhatikan ialah:

1) Harus disadari bahwa utang itu merupakan alternatif terakhir ketika segala usaha untuk mendapatkan dana secara halal dan tunai mengalami kebuntuan. Ada unsur keterpaksaan di dalamnya dan bukan unsur kebiasaan. Ini merupakan dua hal yang berbeda. Keterpaksaan mencerminkan semangat membangun kemandirian dan berusaha mengoptimalkan potensi yang ada semaksimal mungkin. Namun karena keterbatasan yang tidak sanggup diatasi, akhirnya terpaksa memilih jalan utang.

2) Jika terpaksa berutang, jangan berutang di luar kemampuan. Inilah yang dalam istilah syariah disebut dengan ghalabatid dayn atau terbelit utang. Ghalabatid dayn ini akan menimbulkan efek yang besar, yaitu gharir rijal atau mudah dikendalikan pihak lain. Oleh karena itu Rasulullah saw., selalu memanjatkan doa agar beliau senantiasa dilindungi dari penyakit ghalabatid dayn yang 
menyebabkan harga diri atau izzah menjadi hilang. ${ }^{254}$

3) Jika utang telah dilakukan, harus ada niat untuk membayarnya. Harus memiliki komitmen untuk mengembalikan utang. Memperlambat membayar utang bagi yang mampu merupakan sebuah kezaliman, sehingga diperbolehkan untuk mempermalukannya. Dalam konteks mikro, akan sangat mudah akan sangat mudah menerapkan prinsip ini. Misalnya, pengusaha yang tidak mau membayar utang boleh saja dipermalukan dengan cara menyita asetnya, dilarang berpergian ke luar negeri atau menghukum dengan hukuman yang berat. ${ }^{255}$

c. Adab Pemberi dan Penerima Hutang

Beberapa hal yang menjadi sebuah amal ibadah antar sesama (hablun minannaas) dan untuk menghindari masalah dikemudian hari akibat transaksi hutang, ada adab yang harus diketahui oleh pihak pemberi maupun penerima hutang. Adab pemberi hutang :

1) Sebaiknya memberikan hutang kepada orang yang benar-benar membutuhkan

2) Memberi hutang dengan niat bertolong menolong dalam kebajikan

3) Sebaiknya memberikan waktu/tempo pembayaran kepada yang meminjam agar ada kemampuan maupun kemudahan untuk membayar

4) Sebaiknya jangan menagih sebelum waktu pembayaran yang telah disepakati sebelumnya

5) Hendaknya menagih dengan sikap yang lembut dan persuasif

6) Diperkenankan meminta orang lain untuk menagih hutang dengan

${ }^{254}$ Nurul Huda,. Dalam Keuangan Publik Islami; Pendekatan Teoritis dan Sejarah, (Jakarta: Kencana, 2012). hlm 260-261

255 Sukri Iska,. Sistem Perbankan Sayriah di Indonesia dalam Persperspektik Fikih Ekonomi, (Yogyakarta: Fajar Media Press, 2012). Hlm 179. 
terlebih dahulu member nasihat agar bersikap baik, bertutur kata lembut dan penuh pemaaf kepada orang yang akan ditagih

7) Tidak mensyaratkan tambahan/imbalan atas jumlah hutang sesuai dengan kaidah fiqih

8) Memberikan penangguhan waktu kepada orang yang mengalami kesulitan dalam pelunasan setelah jatuh tempo dan mengikhlaskan untuk sedekah sebagian atau keseluruhan hutang tersebut adalah perbuatan yang lebih baik.

Adab Peminjam (Penerima Hutang):

1) Berhutang hanya dalam keadaan terpaksa/sulit

2) Tidak menunda-nunda dalam membayar hutang

3) Berniat sungguh-sungguh untuk melunasi

4) Menunda pelunasan hutang adalah kezaliman

5) Apabila belum diberikan kemampuan untuk membayar hutang hendaknya banyak berdoa kepada Allah agar diberikan kemudahan untuk melunasi.

6) Berupaya untuk berhutang dari orang sholeh yang memiliki profesi dan penghasilan yang halal, dengan demikian diharapkan hutang tersebut dapat menenangkan jiwa dan mendatangkan keberkahan.

7) Jika terjadi keterlambatan membayar karena kesulitan keuangan, hendaklah orang yang berhutang memberitahukan kepada yang memberikan pinjaman.

8) Menggunakan uang pinjaman dengan sebaik mungkin seraya menyadari bahwa pinjaman merupakan amanah yang harus dikembalikan.

9) Disunnahkan melafalkan tahmid (Alhamdulillah) manakala hutang telah terbayar sebagai rasa syukur kepada Allah.

d. Sikap Nabi Muhammad Saw Terhadap Hutang 
Nabi kita Muhammad saw selain diutus menjadi seorang nabi dan rasul terakhir bagi ummatnya, ternyata juga diberikan bakat karunia sebagai seorang pedagang, seorang entrepreneur yang sukses dan dikagumi baik sesama kabilah pedagang dalam sukunya maupun kabilah pedagang yang berasal dari suku lain bahkan dari jazirah/negara lain. Sehingga dengan demikian Nabi Muhammad saw tidaklah asing dengan transaksi perdagangan yang sifatnya tunai maupun non tunai (hutang). Diawal pembelajarannya sebagai seorang pedagang, Nabi Muhammad saw memulai perdagangannya dengan berhutang kepada saudagar kaya yang kemudian menjadi istrinya, Khadijah al Kubro. Beliau membawa barang dagangan milik Khadijah bersama pamannya Abu Thalib untuk diperdagangkan di kota Thaif dan kota-kota lainnya.

Proses 'membawa' barang dagangan ini sudah tentu dicatat baik oleh Nabi Muhammad saw selaku pembawa barang dagangan maupun oleh Khadijah selaku pemilik barang dagangan. ${ }^{256}$

Berbekal pengetahuan dan pengalamannya, nabi sangat tegas dalam menyikapi hutang piutang, beliau pernah bersabda:

"Dari Abu Hurairah, dari Nabi Muhammad saw bersabda: "Barang siapa yang mengambil harta seseorang (berhutang) yang bermaksud untuk membayarnya maka Allah akan melaksanakan pembayaran itu. Dan barangsiapa yang mengambilnya (berhutang) dengan maksud untuk merusak (tidak mau membayar dengan sengaja) maka Allah akan merusak orang itu." (HR Bukhari).

Dilain hadits sebagaimana di riwayatkan Muslim, Nabi Muhammad berkata, "Diampuni semua dosa bagi orang yang mati syahid, kecuali jika ia mempunyai hutang." Hadits ini menandakan pentingnya kedudukan hutang dimata nabi sampai memberikan early

256 Ramdansyah,. Esiensi Hutang Dalam Konsep Ekonomi Islam, Jurnal Bisnis, Vol. 4, No. 1, Juni 2016. hlm 124-135 
warning bagi umatnya yang akan berjihad untuk melunasi hutangnya (bila ada) sebelum berangkat ke medan perang membela ajaran agama islam. Nabi juga bersabda: "Barang siapa yang melepaskan kesengsaraan saudaranya, maka Allah akan melepaskan berbagai kesengsaraan yang dihadapinya." (HR Muslim). Dengan memberikan hutang kepada saudara kita yang membutuhkan, hal itu juga berarti kita membantu saudara kita tersebut lepas dari kesengsaraan. ${ }^{257}$

e. Bahaya Kebiasaan Berhutang

Nabi Muhammad saw memang memperkenankan hutang sebagaimana dalam ajaran yang dibawanya, namun Rasulullah juga mengajarkan kepada umatnya untuk menghindari berhutang karena menurutnya hutang dapat membawa mudharat lain bagi seseorang, sebagaimana dalam salah satu hadits yang diriwayatkan Bukhari: "Sesungguhnya seseorang apabila berhutang, maka dia sering berkata lantas berdusta, dan berjanji lantas memungkiri." Hutang menurut Rasulullah cenderung membuat seseorang (yang berhutang) banyak bicara (mencari alasan-alasan untuk menunda pembayaran) sehingga berpotensi untuk melakukan kedustaan, banyak memberikan janji mengenai tanggal dan hari pelunasan yang juga berpotensi untuk diingkari. Rasulullah juga pernah diriwayatkan menolak menshalatkan jenazah seseorang yang diketahui masih meninggalkan hutang dan tidak meninggalkan harta untuk melunasinya. ${ }^{258}$

Hutang atau mempunyai kebiasaan berhutang akan mendatangkan kerisauan dan kehinaan, hal ini ditegaskan Rasulullah dalam sebuah hadits lain yang diriwayatkan Baihaqi: "Berhati-hatilah

257 Ibid.

258 Ramdansyah,. Esiensi Hutang Dalam Konsep Ekonomi Islam, Jurnal Bisnis, Vol. 4, No. 1, Juni 2016. hlm 124-135. 
kamu dalam berhutang, sesungguhnya hutang itu mendatangkan kerisauan di malam hari dan menyebabkan kehinaan di siang hari.". Hadits ini secara nyata dan tegas menganjurkan kepada kita agar menjauhi hutang, jika diberikan kemampuan membeli secara tunai hendaklah jauhi berhutang (membayar dengan tempo). ${ }^{259}$

\section{Kesimpulan}

Dalam konteks keislaman, pengelolaan harta/keuangan yang dilakukan harus dalam koridor pemenuhan kemaslahatan. Sikap ini melahirkan suatu bahwa dalam Islam membuat perencanaan keuangan keluarga harus bertujuan untuk mencapai falah (sejahtera dunia dan akhirat), menghindari cara-cara yang maisir, gharar, riba dan zalim baik dalam mengumpulkan pendapatan maupun dalam membelanjakannya, mengutamakan sadaqah meskipun rizki sedang sempit, dan menjauhi sifat boros serta sifat yang suka berhutang.

Secara teknis membuat perencanaan keuangan keluarga tiadaklah susah atau rumit diterapkan. Hal awal yang harus dilakukan, yaitu: menentukan tujuan keuangan keluarga, baik jangka pendek, menengah, dan panjang, mengetahui kemampuan keuangan saat ini dan potensi keuangan di masa depan, membuat laporan arus kas, laporan neraca, dan anggaran keuangan keluarga, dalam melakukan investasi, profil risiko pribadi perlu diketahui, apakah konservatif, moderat. atau agresif, dan mengetahui cara atau model perencanaan keuangan yang efektif dan mudah dipahami.

Mengacu pada kerangka pengelolaan keuangan keluarga tersebut di atas maka pemanfaatan pendapatan harus mencakup untuk tujuan kebahagiaan hidup di dunia dan kesuksesan hidup di akhirat. Oleh karenanya, masalah keuangan keluarga bisa diminimalisir 
sehingga resiko berhutang bisa dipersempit. Hidup bisa tenang tanpa berhutang.

\section{Daftar Pustaka}

Al-Qur'an Al-Karim.

Baron dan Donn Byrne,. 2003. Psikologi Sosial, Terj. Jakarta: Erlangga.

Cahyadi, Ady ,. 2014. Mengelolah Hutang Dalam Perspektif Islam. Esensi-Jurnal Bisnis dan Manajemen. Vol. 4, No.1.

Hasibuan, Zainal,. 2007. Metodologi Penelitian Pada Bidang Ilmu Komputer dan Teknologi Informasi. Jakarta : Fikom UI.

Huda, Nurul,. 2012. Dalam Keuangan Publik Islami; Pendekatan Teoritis dan Sejarah, Jakarta: Kencana.

Iska, Sukri. 2012. Sistem Perbankan Sayriah di Indonesia dalam Persperspektik Fikih Ekonomi, Yogyakarta: Fajar Media Press.

Japari, Antony,. 2012. Konsep Perencanaan Keuangan Keluarga, Dokumen Internal, Financial Planner Assosiasi Indonesia.

Mandell, Lewis, and Linda Schemid Klein,. 2009. The Impact of Financial Literacy Education on Subsequent Financial Behavior, Journal of Financial Counseling and Planning, Volume 20.

Minuchin,. 1999. Families and Family Therapy. Cambridge, MA: Harvard University Press.

Ramdansyah,. 2016. Esiensi Hutang Dalam Konsep Ekonomi Islam, Jurnal Bisnis, Vol. 4, No. 1.

Richard R Clayton,. 2003. The Family, Mariage and Social Change, USA:Lawrence Elbraum Press.

Syaparuddin,. 2014. Pengelolaan Keuangan Keluarga Secara Profesional Dalam Mewujudkan Keluarga Sakinah. AlRisalah-Jurnal Hukum Keluarga Islam, Volume 1 No. 1. 
Vangelis, Anita L,. 2004. Handbook of Family Comunication, USA:Lawrence Elbraum Press.

* Alumni Program Pascasarjana Universitas Islam Indonesia Yogyakarta dan Alumni Fakultas Syariah dan Ekonomi Islam IAIN Palu 